\title{
Assessment of dentists' awareness and knowledge levels on the Novel Coronavirus (COVID-19)
}

\section{Güzide Pelin SEZGIN(a) iD Belen ŞIRINOĞLU ÇAPAN ${ }^{(b)}$ iD \\ (a) University of Biruni, Faculty of Dentistry, Department of Endodontics, İstanbul, Turkey. \\ (b) University of Biruni, Faculty of Dentistry, Department of Pediatric Dentistry, İstanbul, Turkey.}

\begin{abstract}
Coronavirus disease-2019 (COVID-19) is the most recent infectious disease that is spreading rapidly throughout the world. This study aimed to evaluate the knowledge and awareness levels of dentists on COVID-19. This survey study, consisting of 37 questions, was sent to dentists via an online link in the first two weeks of April 2020. The questionnaire consisted of questions related to the knowledge level of dentists on COVID-19 during the pandemic period. The knowledge level of dentists was assessed with a 24-point scoring, consisting of correct answers. A Chi-square test was used to compare qualitative data $(\mathrm{p}<0.05)$. A total of 267 dentists participated in this study, of which $51.7 \%$ were aged under 30 years, and $67 \%$ were women. The participants' knowledge level means score was $19.03 \pm 3.15$. According to these results, 231 were determined $(86.5 \%)$ as high knowledgeable. Positive associations between increased knowledge level and factors such as being a woman, working in a university hospital, and being informed outside the institution were determined. The knowledge level of the dentists working in Istanbul about the COVID-19 pandemic is quite high.
\end{abstract}

Keywords: Awareness; COVID-19; Coronavirus; Dentistry; Knowledge.

\section{Introduction}

Coronavirus-19 disease, called COVID-19, is the most recent infectious disease that is spreading rapidly throughout the world. Coronaviruses $(\mathrm{CoV})$ are zoonotic pathogens transferable from animals to humans and humans to humans. SARS-CoV (Severe Acute Respiratory SyndromeCoronavirus) was reported with 8098 infected cases and 774 deaths in China between the years of 2002 and 2003. Even though the actual cause of this syndrome is still unidentified, it has been suggested that it was transferred from bats to other mammals. ${ }^{1}$ Middle East Respiratory Syndrome-Coronavirus (MERS-CoV) was a viral epidemic that occurred in Saudi Arabia in 2012. Even though its origin showed similarities with SARS-CoV, 860 deaths were reported in that epidemic., ${ }^{1,3}$ COVID-19 is different from SARS-CoV; however, their surface receptor is similar (human angiotensin-converting enzyme 2 (ACE2)). COVID-19 was first discovered in Wuhan, China. Unfortunately, the outbreak that emerged in Asia has spread rapidly throughout the world from 2019 to 2020. It was
Submitted: May 11, 2020

Accepted for publication: July 8, 2020

Last revision: July 24, 2020 
declared a pandemic by the World Health Organization (WHO) on March 11, 2020. As of June 7, 2020, a total of 6.750 .521 infected cases and 395.779 deaths have occurred worldwide due to this disease.

COVID-19 can be transmitted from humans to humans by droplets via coughing, sneezing, or by direct contact, and the incubation period of the disease was reported as 2-14 days. ${ }^{4}$ Even though various drugs have been suggested for COVID-19, no definitive antiviral therapy or vaccine has yet been discovered. For this reason, preventive measures are of utmost and vital importance in bringing this infection under control. Healthcare workers have been considered to be in the high-risk group for this disease due to their direct contact with infected patients. An article published in the New York Times newspaper on March 15,2020 reported that the occupational group with the highest risk of being affected by COVID-19 were dentists, even higher than nurses and physicians. ${ }^{5}$ Dentists may play a significant role in preventing the spread of the infection by paying attention to protective equipment and disinfection, since they work inside the oral cavity and make contact the saliva of different patients. Therefore, using the appropriate personal protective equipment such as gloves, masks, eyeglasses, and bonnets during routine dental procedures has the utmost importance in the transmission of and infection with various viral and bacterial agents. ${ }^{6}$ COVID-19 disease can be transmitted directly by inhalation of aerosolized and airborne particles arising during dental procedures or by direct mucosal contact due to feeding and saliva droplets. ${ }^{7,8}$ Besides, studies have shown that the virus can stay alive for specific periods on various objects and surfaces infected by the virus within the last nine days. ${ }^{9}$ Since the viral burden in the infected human saliva is high, using antiseptic mouthwash can reduce infectiousness, but does not eliminate the virus within saliva. ${ }^{79}$ Besides the use of protective equipment in full by dentists, ventilation of the environment, and disinfection of the surfaces that patients are in touch with are also important. Guidelines published in this context suggest that dentists should postpone non-emergency treatments during the outbreak. ${ }^{10,11,12}$ On the other hand, it was suggested that the body temperature of the patient should be measured $\left(37.5^{\circ} \mathrm{C}\right.$ and over), and information should be obtained from the patient regarding their health status during the last seven days, traveling abroad, and the risk of haven been in contact with infected individuals. ${ }^{13}$ Knowing that the COVID-19 virus is inactivated by water, soap, detergents, and disinfectants, the most significant preventive measure in addition to those mentioned above is the provision of maximum hand and surface hygiene. ${ }^{13}$

Currently, while countries are struggling with the COVID-19 pandemic, dentists have to change their routine clinical attitudes and behaviors. In the light of the guidelines published up to now, dentists being knowledgeable about the COVID-19 pandemic and its transmission routes are essential with regard to the reduction of the risk of cross-infection between the patient, dentist, and dental assistant, thus slowing down the pandemic. Therefore, the present study aimed to evaluate the knowledge levels and perceptions of dentists with regard to the preventive measures that should be taken before and after dental procedures, and the dental treatments that should be performed during the pandemic.

\section{Methodology}

This study was approved by the Ethics Committee of Biruni University (2020/39-01). Participation in this survey study was completely voluntary and anonymous. It was assumed that the participants who responded to the anonymous questionnaire had given their consent to participate in the study. Besides, this study was conducted in compliance with the Helsinki-2013 declaration. The 37-question questionnaire, which was prepared in the light of the guidelines published by the FDI World Dental Federation, ${ }^{10}$ American Dental Association (ADA), ${ }^{11}$ and Turkish Dental Association (TDA) ${ }^{12}$ during the COVID-19 pandemic, was organized using Google Forms. First, a pilot study was performed on randomly selected 20 dentists to validate the questionnaire and its Cronbach's alpha was obtained to be 0.78 . The pilot study responses were excluded from the final study.

The sample size required for the study was calculated based on the total number of dentists $(9,312)$ in İstanbul. The minimum sample size was 
calculated as 240 according to the power calculation for this study. The questionnaire was directed to a total of 504 dentists working in Istanbul, through an online link via social media platforms such as WhatsApp and Facebook. Incomplete or blank questionnaires were excluded from the study. This survey study was responded by dentists/ specialists in dentistry in the first two weeks of April 2020. The survey consisted of three parts: the first part involved questions related to the personal characteristics of the participants (5 questions), the second part questioned the level of knowledge on COVID-19 (9 questions), and the last part involved questions investigating participants' perspectives on routine and emergency dentistry practices during the pandemic (23 questions). A 24-point scoring system was developed to assess the knowledge levels of the dentists (Table 1). Total knowledge level

Table 1. Scoring of the knowledge level.

\begin{tabular}{|c|c|c|}
\hline Scoring item & Answer & Score \\
\hline The incubation period of Covid-19 is (2-14) days. & Yes & 1 \\
\hline The symptoms of Covid-19 have been reported as fever, cough, and difficulty in breathing. & Yes & 1 \\
\hline Hand hygiene has the utmost importance in the transmission of COVID-19 disease. & Yes & 1 \\
\hline $\begin{array}{l}\text { Do you think that routine dental procedures should be continued if necessary precautions are taken during the } \\
\text { COVID-19 pandemic, such as protective equipment, isolated areas, and adequate ventilation? }\end{array}$ & No & 1 \\
\hline I do not perform dental treatment if the patient has a fever equal to or greater than $37.5^{\circ} \mathrm{C}$. & Yes & 1 \\
\hline $\begin{array}{l}\text { Would you perform dental procedures which do not create aerosol (not requiring aerator use) during the } \\
\text { COVID-19 pandemic? }\end{array}$ & No & 1 \\
\hline Would you extract an asymptomatic tooth? & No & 1 \\
\hline $\begin{array}{l}\text { While performing dental procedures during the COVID-19 pandemic, if there is no N95 / FFP3 mask, is it } \\
\text { sufficient to wear a } 2 \text {-fold standard mask? }\end{array}$ & No & 1 \\
\hline Do you think that standard dental suction is appropriate procedure to be performed during the COVID-19 pandemic? & No & 1 \\
\hline Should the patient gargle before the dental procedure during the COVID-19 pandemic? & Yes & 1 \\
\hline Do you think that emergency dental procedures should be performed during the COVID-19 pandemic? & Yes & 1 \\
\hline I perform an emergency intervention in acute pulpitis and treat the patient in a single session. & No & 1 \\
\hline $\begin{array}{l}\text { I perform only the extirpation and complete the treatment during a second session within the period of the } \\
\text { COVID- } 19 \text { pandemic in acute pulpitis. }\end{array}$ & No & 1 \\
\hline I perform only the extirpation and complete the treatment during a second session after the pandemic. & Yes & 1 \\
\hline I perform emergency treatment when extraoral swelling and localized pain are present. & Yes & 1 \\
\hline $\begin{array}{l}\text { When extraoral swelling and localized pain are present, I prescribe antibiotics and anti-inflammatory drugs only, } \\
\text { and postpone the treatment to an appointment after the pandemic. }\end{array}$ & No & 1 \\
\hline I perform treatment in cases with complicated trauma. & Yes & 1 \\
\hline I intervene in patients with uncontrolled bleeding following tooth extraction. & Yes & 1 \\
\hline I perform treatment in cases with osteitis, alveolitis, pericoronitis, and third molar pain. & Yes & 1 \\
\hline I perform treatment in cases such as acute and painful lesions of the oral mucosa and periodontal abscess. & Yes & 1 \\
\hline $\begin{array}{l}\text { I intervene emergently in patients who are receiving or who are planned to receive radiotherapy and } \\
\text { chemotherapy or in patients with organ transplants. }\end{array}$ & Yes & 1 \\
\hline I perform final crown/bridge cementation if the temporary restoration is lost, broken, or causing gingival irritation. & Yes & 1 \\
\hline I remove stitches. & Yes & 1 \\
\hline $\begin{array}{l}\text { I perform treatment if there is pain in cases undergoing orthodontic treatment in whom the brackets and wires } \\
\text { are dislocated or broken. }\end{array}$ & Yes & 1 \\
\hline Total & & 24 \\
\hline
\end{tabular}

Scoring: (0) - uninformed, (1-8) - low knowledgeable, (9-16) - moderately knowledgeable, (17-24) - high knowledgeable. 
was calculated based on each dentist's response. Each correct response was given a score of "1" and incorrect response a score of " 0 ". The total score of the dentists was calculated by collecting the scores which ranged from 0 to 24, on a Likert Scale. According to this, the knowledge levels were categorized as uninformed (0), low knowledgeable (1-8), moderately knowledgeable (9-16), and high knowledgeable (17-24). The study data were obtained by internet e-survey results established by Google Forms.

\section{Statistical analysis}

Statistical analyses were performed using IBM SPSS $22^{\text {nd }}$ version (SPSS IBM, Turkey). In the statistical analysis of the study data, in addition to descriptive statistical methods (Mean, Standard Deviation, Frequency), the Chi-Square, Fisher's Exact Chi-Square, and Fisher-Freeman-Halton tests were used for the comparison of the qualitative variables. Significance was assessed at a level of $\mathrm{p}<0.05$

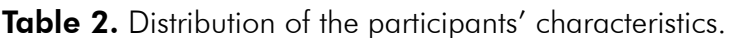

\begin{tabular}{|c|c|c|}
\hline Variable & $\mathrm{n}$ & $\%$ \\
\hline \multicolumn{3}{|l|}{ Age } \\
\hline$<30$ & 138 & 51,7 \\
\hline$>30$ & 129 & 48,3 \\
\hline \multicolumn{3}{|l|}{ Gender } \\
\hline Male & 88 & 33 \\
\hline Female & 179 & 67 \\
\hline \multicolumn{3}{|l|}{ Years of practice } \\
\hline Less than 5 years & 117 & 43,8 \\
\hline $5-9$ years & 73 & 27,3 \\
\hline 10 years and over & 77 & 28,8 \\
\hline \multicolumn{3}{|l|}{ Speciality } \\
\hline Yes & 95 & 35,6 \\
\hline No & 172 & 64,4 \\
\hline \multicolumn{3}{|l|}{ Institution } \\
\hline Nonworker & 47 & 17,6 \\
\hline $\begin{array}{l}\text { State hospital/Oral and dental health } \\
\text { center }\end{array}$ & 39 & 14,6 \\
\hline Private hospital/Clinic & 87 & 32,6 \\
\hline University hospital & 94 & 35,2 \\
\hline
\end{tabular}

\section{Results}

A total of 267 (52.9\%) dentists with an age range between 21 and 65 years participated in the study, although it targeted 504 dentists. The mean age of the participants was $30.56 \pm 8.33$ years. The demographic characteristics of the participants are shown in Table 2 .

A total of $58.1 \%$ of the dentists stated that they were given information on COVID-19 and dentistry in their institutions. Most of the participants $(82 \%)$ were determined to be informed about COVID-19 and dentistry outside their institutions. The primary sources of information were the Ministry of Health, Turkish Dental Association, and internet/Youtube (Table 3).

Table 3. Responses according to the information obtained about COVID-19, source of information, and transmission routes of COVID-19.

\begin{tabular}{|c|c|c|}
\hline Variable & $\mathrm{n}$ & $\%$ \\
\hline \multicolumn{3}{|c|}{ Obtaining information on COVID-19 in their institution } \\
\hline Yes & 155 & 58,1 \\
\hline No & 112 & 41,9 \\
\hline \multicolumn{3}{|c|}{ Obtaining information on COVID-19 from outside their institution } \\
\hline Yes & 219 & 82 \\
\hline No & 48 & 18 \\
\hline \multicolumn{3}{|c|}{ External source of information $(n=219)$} \\
\hline Ministry of Health & 176 & 80,4 \\
\hline TDA & 168 & 76,7 \\
\hline WHO & 130 & 59,4 \\
\hline International articles & 71 & 32,4 \\
\hline National articles & 38 & 17,4 \\
\hline Internet/YouTube & 146 & 66,7 \\
\hline \multicolumn{3}{|l|}{ Transmission routes of COVID-19 } \\
\hline Droplets & 265 & 99,3 \\
\hline Saliva & 243 & 91 \\
\hline Contact with objects or surfaces & 234 & 87,6 \\
\hline Contact with an individual & 244 & 91,4 \\
\hline Blood & 86 & 32,2 \\
\hline Air & 130 & 48,7 \\
\hline
\end{tabular}




\section{Knowledge and Perceptions about COVID-19}

When dentists were asked about the transmission routes of COVID-19, almost all of them (99.3\%) responded that it was by droplets, and most of them $(91 \%, 91.4 \%$, and $87.6 \%)$ responded that it was transmitted by contact with saliva, persons, and objects, respectively. Most of the dentists (81.3\%) said that the hygienic hand washing duration was 20 seconds. Approximately two-thirds of the participants $(67.4 \%)$ stated that both soap and disinfectants are required for hygienic hand washing. Of 248 (92.8\%) dentists who thought that a patient should gargle before a dental procedure during the COVID-19 pandemic, $61.7 \%$ chose chlorhexidine, $52 \%$ hydrogen peroxide, and $43.1 \%$ povidone-iodine, respectively.

Even though $66.3 \%$ of dentists replied that "when an extraoral abscess and localized pain is present, I prescribe antibiotics and anti-inflammatory drugs and postpone the procedure to an appointment after the pandemic," $95.5 \%$ of dentists replied that when their analgesic preferences were questioned, a great majority of these participants (85.9\%) preferred paracetamol (Table 4).

Table 4. Dentists' preferences regarding the duration and style of hygienic handwashing, type of mouthwash, and analgesic

\begin{tabular}{lcc}
\hline Variable & $\mathrm{n}$ & $\%$ \\
\hline Duration of hygienic handwashing & & \\
$20 \mathrm{~s}$ & 217 & 81,3 \\
$30 \mathrm{~s}$ & 31 & 11,6 \\
$40 \mathrm{~s}$ & 19 & 7,1 \\
Style of hygienic handwashing & & \\
Only soap & 87 & 32,6 \\
$\quad$ Both soap and disinfectant & 180 & 67,4 \\
Mouthwash preference ( $\mathrm{n}=248)$ & & \\
$\quad$ Chlorhexidine & 153 & 61,7 \\
$\quad$ Povidone-iodine & 107 & 43,1 \\
Hydrogen peroxide & 129 & 52 \\
Analgesic preference $(\mathrm{n}=255)$ & & 85,9 \\
$\quad \begin{array}{l}\text { Paracetamol } \\
\text { Ibuprofen }\end{array}$ & 219 & 36,9 \\
Acetyl salicylic acid & 94 & 13,3 \\
\hline
\end{tabular}

The distributions of the answers to the questions evaluating the knowledge level of the participants are shown in Table 5. The participants' knowledge level score ranged between 7 and 24, and the mean score was $19.03 \pm 3.15$. According to these results, $4(1.5 \%)$ were determined to be low knowledgeable, 32 (12\%) moderately knowledgeable, and 231 (86.5\%) high knowledgeable.

The analysis of knowledge level according to age, gender, professional experience, specialty, institution, and whether they were informed about COVID-19 or not is shown in Table 6. According to the knowledge level analysis, the proportion of high knowledgeable about COVID-19 female dentists on COVID-19 (91.1\%) was significantly higher than that of the males $(77.3 \%)(p=0.002 ; p<0.05)$. Even though the proportion of high knowledgeable about COVID-19 in specialist dentists (92.6\%) was higher than in dentists with no specialty $(83.1 \%)$, the difference was close to the significance border, but not statistically significant $(p>0.05)$. There was a statistically significant difference regarding the knowledge level about COVID-19 among the institutions where the participants worked (p: 0.002; $\mathrm{p}<0.05$ ). The proportion of high knowledgeable about COVID-19 among dentists working in university hospitals $(92.6 \%)$ was significantly higher than in dentists working in private hospitals/clinics (81.6\%) and state hospitals/oral and dental health centers (79.5\%) (p1: 0.021; p2: 0.021; $<$ 0.05). The proportion of high knowledgeable about COVID-19 in non-worker dentists $(89.4 \%)$ was significantly higher than in dentists working in private hospitals/clinics (81.6\%) and state hospitals/oral and dental health centers (79.5\%) (p1:0.004; p2:0.013; p < 0.05). Additionally, the proportion of high knowledgeable about COVID-19 in dentists informed about COVID-19 outside their institution (90\%) was significantly higher than the others. $(70.8 \%)(p=0.001 ; p<0.05)$ (Table 6).

\section{Discussion}

Currently, COVID-19 is a global matter of debate throughout the world, particularly among healthcare workers and patients. Dentists are considered to be at high risk regarding nosocomial infections and may 
Table 5. Distribution of dentists' knowledge on COVID-19

\begin{tabular}{|c|c|c|c|c|}
\hline \multirow{2}{*}{ Variable } & \multicolumn{2}{|c|}{ No } & \multicolumn{2}{|c|}{ Yes } \\
\hline & $\mathrm{n}$ & $\%$ & $\mathrm{n}$ & $\%$ \\
\hline The incubation period of Covid-19 is (2-14) days. & 2 & 0,7 & 265 & 99,3 \\
\hline The symptoms of Covid-19 have been reported as fever, cough, and difficulties in breathing. & 1 & 0,4 & 266 & 99,6 \\
\hline Hand hygiene has the utmost importance in the transmission of COVID-19. & 0 & 0 & 267 & 100 \\
\hline $\begin{array}{l}\text { Do you think that routine dental procedures should be continued if necessary } \\
\text { precautions are taken during the COVID-19 pandemic, such as protective equipment, } \\
\text { isolated areas, and adequate ventilation? }\end{array}$ & 230 & 86,1 & 37 & 13,9 \\
\hline I do not perform dental treatment if the patient has a fever equal to or greater than $37.5^{\circ} \mathrm{C}$. & 16 & 6 & 251 & 94 \\
\hline $\begin{array}{l}\text { Would you perform dental procedures which do not create aerosol (not requiring } \\
\text { aerator use) during the COVID- } 19 \text { pandemic? }\end{array}$ & 159 & 59,6 & 108 & 40,4 \\
\hline Would you extract an asymptomatic tooth? & 143 & 53,6 & 124 & 46,4 \\
\hline $\begin{array}{l}\text { While performing dental procedures during the COVID-19 pandemic, if there is no } \\
\text { N95 / FFP3 mask, is it enough to wear a 2-fold standard mask? }\end{array}$ & 237 & 88,8 & 30 & 11,2 \\
\hline $\begin{array}{l}\text { Do you think that standard dental suction is an appropriate procedure to be performed } \\
\text { during the COVID-19 pandemic? }\end{array}$ & 252 & 94,4 & 15 & 5,6 \\
\hline Should the patient gargle before the dental procedure during the COVID-19 pandemic? & 19 & 7,1 & 248 & 92,9 \\
\hline $\begin{array}{l}\text { Do you think that emergency dental procedures should be performed during the } \\
\text { COVID-19 pandemic? }\end{array}$ & 18 & 6,7 & 249 & 93,3 \\
\hline $\begin{array}{l}\text { I perform an emergency intervention in acute pulpitis and treat the patient in a } \\
\text { single session. }\end{array}$ & 178 & 66,7 & 89 & 33,3 \\
\hline $\begin{array}{l}\text { I perform only the extirpation and complete the treatment during a second session within } \\
\text { the period of the COVID-19 pandemic in acute pulpitis. }\end{array}$ & 164 & 61,4 & 103 & 38,6 \\
\hline $\begin{array}{l}\text { I perform only the extirpation and complete the treatment in the second session after the } \\
\text { pandemic. }\end{array}$ & 54 & 20,2 & 213 & 79,8 \\
\hline I perform emergency treatment when extraoral swelling and localized pain are present. & 73 & 27,3 & 194 & 72,7 \\
\hline $\begin{array}{l}\text { When extraoral swelling and localized pain are present, I prescribe antibiotics and } \\
\text { anti-inflammatory drugs only and postpone the treatment to an appointment after the } \\
\text { pandemic. }\end{array}$ & 90 & 33,7 & 177 & 66,3 \\
\hline I perform treatment in cases with complicated trauma. & 43 & 16,1 & 224 & 83,9 \\
\hline I intervene in patients with uncontrolled bleeding following tooth extraction. & 18 & 6,7 & 249 & 93,3 \\
\hline I perform treatment in cases with osteitis, alveolitis, pericoronitis, and third molar pain. & 36 & 13,5 & 231 & 86,5 \\
\hline $\begin{array}{l}\text { I perform treatment in cases such as acute and painful lesions of the oral mucosa and } \\
\text { periodontal abscess. }\end{array}$ & 45 & 16,9 & 222 & 83,1 \\
\hline $\begin{array}{l}\text { I intervene emergently in patients who are receiving or who have been scheduled to } \\
\text { receive radiotherapy and chemotherapy or in patients with organ transplants. }\end{array}$ & 69 & 25,8 & 198 & 74,2 \\
\hline $\begin{array}{l}\text { I perform final crown/bridge cementation if the temporary restoration is lost, broken, } \\
\text { or causing gingival irritation. }\end{array}$ & 111 & 41,6 & 156 & 58,4 \\
\hline I remove stitches. & 53 & 19,9 & 214 & 80,1 \\
\hline $\begin{array}{l}\text { I perform treatment if there is pain in cases undergoing orthodontic treatment in whom } \\
\text { the brackets and wires are dislocated or broken. }\end{array}$ & 86 & 32,2 & 181 & 67,8 \\
\hline
\end{tabular}

be potential carriers of COVID-19. This study aimed to determine the awareness and knowledge level of dentists in Istanbul regarding COVID-19 and to help in identifying the knowledge gaps.
Most of the dentists who participated in present study were women $(67 \%)$. This situation originates from the fact that many female students worldwide prefer dentistry due to its working hours and 
Table 6. Association between dentists' characteristics and COVID-19 knowledge levels.

\begin{tabular}{|c|c|c|c|c|}
\hline \multirow{2}{*}{ Variable } & $\begin{array}{l}\text { Low } \\
\text { knowledgeable }\end{array}$ & $\begin{array}{c}\text { Moderately } \\
\text { knowledgeable }\end{array}$ & $\begin{array}{c}\text { High } \\
\text { knowledgeable }\end{array}$ & \multirow{2}{*}{$\mathrm{p}$-value } \\
\hline & n (\%) & n (\%) & n (\%) & \\
\hline \multicolumn{5}{|l|}{ Age } \\
\hline$<30$ & $2(1,4 \%)$ & $15(10,9 \%)$ & $121(87,7 \%)$ & ${ }^{\circ} 0,841$ \\
\hline$>30$ & $2(1,6 \%)$ & $17(13,2 \%)$ & 110 (85,3\%) & \\
\hline \multicolumn{5}{|l|}{ Gender } \\
\hline Male & $1(1,1 \%)$ & $19(21,6 \%)$ & $68(77,3 \%)$ & ${ }^{\circ} 0,002^{*}$ \\
\hline Female & $3(1,7 \%)$ & $13(7,3 \%)$ & $163(91,1 \%)$ & \\
\hline \multicolumn{5}{|l|}{ Years of practice } \\
\hline Less than 5 years & $2(1,7 \%)$ & $14(12 \%)$ & 101 (86,3\%) & ${ }^{b} 0,458$ \\
\hline $5-9$ years & $2(2,7 \%)$ & $6(8,2 \%)$ & 65 (89\%) & \\
\hline 10 years and over & $0(0 \%)$ & $12(15,6 \%)$ & $65(84,4 \%)$ & \\
\hline \multicolumn{5}{|l|}{ Specialty } \\
\hline Yes & $0(0 \%)$ & 7 (7,4\%) & $88(92,6 \%)$ & ${ }^{\circ} 0,064$ \\
\hline No & $4(2,3 \%)$ & $25(14,5 \%)$ & $143(83,1 \%)$ & \\
\hline \multicolumn{5}{|l|}{ Institution } \\
\hline Nonworker & $3(6,4 \%)$ & $2(4,3 \%)$ & $42(89,4 \%)$ & $0,002^{*}$ \\
\hline State hospital/Oral and dental health center & $0(0 \%)$ & $8(20,5 \%)$ & $31(79,5 \%)$ & \\
\hline Private hospital/Clinic & $0(0 \%)$ & $16(18,4 \%)$ & $71(81,6 \%)$ & \\
\hline University hospital & $1(1,1 \%)$ & $6(6,4 \%)$ & $87(92,6 \%)$ & \\
\hline \multicolumn{5}{|l|}{ Getting information on COVID-19 in institution } \\
\hline Yes & $2(1,3 \%)$ & $14(9 \%)$ & $139(89,7 \%)$ & ${ }^{\circ} 0,183$ \\
\hline No & $2(1,8 \%)$ & $18(16,1 \%)$ & $92(82,1 \%)$ & \\
\hline \multicolumn{5}{|c|}{ Getting information on COVID-19 from outside institution } \\
\hline Yes & $1(0,5 \%)$ & $21(9,6 \%)$ & 197 (90\%) & ${ }^{\circ} 0,001^{*}$ \\
\hline No & $3(6,3 \%)$ & $11(22,9 \%)$ & $34(70,8 \%)$ & \\
\hline
\end{tabular}

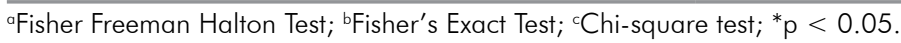

conditions. ${ }^{14}$ Similar to our results, Khader et al. reported that female dentists participated more in their study investigating the perspectives of dentists on the COVID-19 pandemic. ${ }^{15}$ In contrast, Bahagawathula et al. ${ }^{16}$ in their study involving all health workers, such as doctors and nurses, showed that the female-male ratio was almost equal. Dentists who were aged under 30 years and had graduated from the faculty of dentistry in the last five years constituted the majority of the dentists who participated in the study. Similarly, some studies in the literature reported that the majority of participants had less than 5 years of professional experience. ${ }^{17,18}$ In the study that Bahagawathula et al. ${ }^{16}$ conducted online, most of the participants were individuals aged under 30 years. It was explained by the fact that the younger age group was more active and willing to take surveys via social media and to participate in online survey studies.

Most of the participants were found to be working in private clinics or university hospitals. This result was consistent with the study conducted by Khader et al. ${ }^{15}$ We have the opinion that academicians are more sensitive about research studies. The least participation came from physicians working in state hospitals. Dentists are at the forefront of the battle 
against coronavirus in these difficult days. In our country, dentists working in state hospitals have been assigned to control and follow-up infected individuals at their homes. The fact that this group participated might be due to their intense and stressful working pace.

In this study, participants generally stated that they were informed about COVID-19 and dental practices. The fact that the pandemic began in our country in March 2020 suggests that dentists have been rapidly informed about COVID-19. Additionally, this result is affected by the fact that the epidemic started in China and information about the virus and its symptoms has accumulated during the process until it arrived in our country. Participants received extra-institutional information mostly from the Ministry of Health and Turkish Dental Association, followed by the internet and social media. Similar to our results, Bahagawathula et al. stated that participants received information about COVID-19 primarily from state sources and social media. ${ }^{16}$ In contrast to this study results, Kamate et al. determined the primary sources of information to be the internet and social media. ${ }^{17}$ However, because misleading information can be present on the internet, healthcare workers should be more careful about the information they get from the internet, and they should preferably act according to the scientific and reliable sources.

Proven transmission routes of COVID-19 from human to humans are droplets, saliva, or direct contact. ${ }^{19}$ There is no definitive information about other transmission routes, such as blood or air. In the present study, when dentists were asked about the transmission routes of COVID-19, the results showed that most of the participants knew the correct answers. However, approximately half and one third of them replied that air and blood were transmission routes, respectively. This situation revealed that even though the definite transmission routes were well-known, the dentists suspected other routes of transmission, and were more concerned because of the pandemic. In line with the results of this survey, studies in the literature noted that the transmission routes of the disease were correctly known by most dentists. $17,18,20,21,22$
Almost all the dentists who participated in this study had the correct information about the incubation period of the virus, the cardinal signs of the disease (dry cough, dyspnea and fever), and the great importance of hand hygiene in the prevention of the disease. These results were similar to the results of the Khader et al., ${ }^{15}$ Kamate et al., ${ }^{17}$ and Kinariwala et al. ${ }^{22}$ When the dentists were asked about the duration of hygienic handwashing, none of them marked a duration below $20 \mathrm{~s}$. Nevertheless, there were also participants who indicated longer durations for handwashing. These answers should not be considered as wrong because in the guideline related to COVID-19, the duration of handwashing was reported as "at least 20 seconds". ${ }^{23}$ Most of the dentists participating in this survey stated that they prefer to use both soap and disinfectants while providing hand hygiene (67.4\%). However, it was written in the published guidelines that using soap or disinfectant only would be enough to provide hand hygiene. ${ }^{24}$ The opinion of most of the participants that using only one of these would not be enough, may be suggested as the evidence of how individuals, including dentists, were concerned about the pandemic.

Dental applications, which cause aerosolization, lead to virus contamination of dentists, their assistants, and indirectly other patients. ${ }^{25}$ Since the incubation period of the disease is 2-14 days, it is not possible to distinguish asymptomatic but infected patients. Therefore, the American Dental Association (ADA) recommended on March 16, 2020, that dental practice should be limited to emergency procedures only and published the updated procedure list on March 31, $2020 .^{11}$ According to the results of this study, the vast majority of dentists reported that they would not continue performing routine dental treatments during the pandemic and would not intervene in patients with fever. This result revealed that the dentists participating in the survey were quite knowledgeable about the COVID-19 pandemic. However, 14\% of the dentists stated that they would perform routine dental procedures. We could determine whether this situation is due to the level of knowledge or economic causes. 
Most of the dentists participating in this study reported that surgical masks would not provide sufficient protection (88.8\%). Similar to the results obtained from this study, Ahmed et al. stated that $85 \%$ of the participants believed that surgical mask will not provide adequate protection. ${ }^{21}$ Surgical face masks provide approximately $80 \%$ filtration rate when worn correctly. The aerosolized particle sizes of COVID-19 are between 3-100 $\mathrm{nm}$. Using an FFP3 mask provides a $99 \%$ filtration rate of all particles down to $0.6 \mu \mathrm{m}$ in size. ${ }^{26,27}$ In 2008 , the Health and Safety Executive evaluated the protection against influenza bioaerosols provided by various masks and recommended that single-use FFP3 masks should be used while performing clinical procedures that produce aerosols. They also stated that the perception of providing protection against aerosols by regular surgical masks is a common misconception. ${ }^{27}$ On the other hand, in the present study, almost all of the dentists stated that, before dental procedures, patients should be gargled to prevent contamination through aerosolization during the pandemic, and most of them prefer to use chlorhexidine mouthwash. However, a good number of then also preferred to use povidoneiodine and hydrogen peroxide. It has been shown that both SARS and MERS were quite sensitive to povidone-iodine mouthwash. Therefore, gargling the mouth with $0.2 \%$ povidone-iodine before the dental procedure has been suggested to reduce the coronavirus burden in saliva. ${ }^{24,28,29}$ Unfortunately, the study of Ahmed et al. shows that despite their knowledge, most of the dentists did not ask patients to rinse the mouth with an antibacterial mouthwash before dental treatment. ${ }^{21}$

The current approach to COVID-19 is to bring the source of infection under control, take precautions for the prevention of infection and control measures for the reduction of the contamination risk, and to provide supportive care for affected patients. ${ }^{30}$ Consistent with the guidelines and declarations of institutions such as FDI and ADA, most of dentists participating in this study had the opinion that emergency dental procedures should be performed during the pandemic. Most of them stated that they would perform an emergency intervention when acute pulpitis was present, but will complete the canal treatment only after the pandemic. In fact, it was reported that scheduling treatments in at least two sessions and designated isolated areas were better regarding in infection control. ${ }^{23}$ Since there was no similar study in the literature regarding emergency dental procedures during the course of the COVID19 pandemic, we were not able to make a direct comparison. However, we are of the opinion that most of the participants were knowledgeable about this subject.

Generally, participants prefer to prescribe paracetamol-derived analgesics in case of extraoral abscess and localized pain, whereas nearly one-third (36.9\%) of the participants chose ibuprofen derivatives in this study. However, on March 17, 2020, the British Medical Journal recommended using acetaminophen, and not ibuprofen, for analgesia in the treatment of patients infected with COVID-19. This is because it was considered that ibuprofen might interfere with the immune function. ${ }^{31}$ Since we are to consider all patients undergoing dental treatments as probably infected during the pandemic, ibuprofen derivatives must not be prescribed as analgesics, and dentists should be informed on this subject.

Regarding the other emergency dental treatments specified by ADA, most of the participants were determined to be knowledgeable, and the participants stated that they would perform the treatment. For procedures such as final crown/bridge cementation, if the temporary restoration is lost, broken, or causing gingival irritation, the dentists were indecisive, and $41 \%$ of them stated that they would not intervene. However, this situations are considered as emergency dental treatment procedures by both ADA and the Ministry of Health.

In this study, where the level of knowledge was evaluated by scoring, most dentists were determined as high knowledgeable. We are of the opinion that this result is due to the fact that the pandemic entered our country later when compared to other countries, and both the Ministry of Health and dental associations had made great efforts to inform the dentists rapidly. In accordance with the results of the present study, Kamate et al. found that the knowledge levels of most of the dentists 
about COVID-19 were high (92.7\%). ${ }^{17}$ However, Gambhir et al. reported that most of the Indian dentists had a low level of knowledge (38.1\%). ${ }^{20}$ On the other hand, in this study, no significant relationship was found between professional experience and the level of knowledge. Similarly, Gambhir et al. ${ }^{20}$ found no significant relationship between professional experience and the level of knowledge, whereas a significant association was found in the study of Kamate et al. ${ }^{17}$ Considering that accessing information is very easy in today's circumstances, the insignificant relationship between professional experience and knowledge level may not be surprising. Studies in the literature also reported a significant relationship between specialty and level of knowledge. ${ }^{17,20,22,32}$ Even though no statistically significant relationship was found between specialty and knowledge level, the knowledge levels of the dentists having a specialty degree were found to be higher in this study. Besides, the knowledge levels of female dentists were found to be higher than those of male dentists. In accordance with this result, Kinariwala et al. stated that Indian female dentists had higher knowledge levels compared to their male counterparts. ${ }^{22}$ It is thought that the reason why women are more knowledgeable than men is because of their more curious and worrisome nature about current developments. In addition, in this study, the knowledge levels of dentists who were working in university hospitals were found to be higher than those of others. Similarly, Ghambir et al. reported that academicians had higher knowledge scores. ${ }^{20}$ In our country, dentists working in university hospitals are also academicians. We are of the opinion that due to their profession, these dentists keep their knowledge up-to-date by reading from reliable sources more compared to other dentists.

From now on, every patient should be considered as potentially infected by the virus, and during all dentistry procedures, up-to-date infection control policies should be implemented. With this purpose in mind, all dentists should follow the latest information and read reliable and up-to-date sources. As dentists, we have not been using highly-protective equipment in our routine dental treatments until now. However, after this phase, it would be necessary to revise various procedures in dental practice. Many new guidelines regarding dental protective equipment are been published worldwide. Considering the new been published over the world, we should think of the probability of a second and even third attack of the virus, and perhaps predict that we will never return to our old normal routine.

Dentists in Istanbul were correctly informed about COVID-19 symptoms, but partially informed regarding emergency dental treatments. The results of this study will help to determine the exact knowledge gap of dentists with regard to COVID19 and emergency dental treatments. Thus, it will enable dentists to be more informed about these gaps and to formulate better practices and guidelines against COVID-19 spread.

\section{Limitations}

Even though significant results were obtained, it is essential to emphasize that our study had some limitations resulting in a smaller than expected sample size; this might be because data was collected in a short period in order to keep the subject up-to-date. Another limitation is that more young than old dentists participated in the study. This might be because the questionnaire was circulated for a short period online due to the pandemic. Dentists working in Istanbul, which is one of Turkey's most populous and largest city, participated in this study. However, information about the study may not have arrived on time in other parts of the country. Different results could have been obtained with studies involving many regions of Turkey and with more experienced dentists.

\section{Conclusion}

In conclusion, the level of knowledge of the dentists working in Istanbul about the COVID-19 pandemic, its symptoms, transmission routes, preventive measures, and performed treatments is considerably high. However, there are information gaps regarding emergency dental treatments. Further studies with larger sample sizes across the country or world are needed to achieve more comprehensive results. 


\section{References}

1. Crawford B, Kasmidi M, Korompis F, Pollnac RB. Factors influencing progress in establishing community-based marine protected areas in Indonesia. Coast Manage. 2006;34(1):39-64. https://doi.org/10.1080/08920750500379300

2. Elrggal ME, Karami NA, Rafea B, Alahmadi L, Al Shehri A, Alamoudi R, et al. Evaluation of preparedness of healthcare student volunteers against Middle East respiratory syndrome coronavirus (MERS-CoV) in Makkah, Saudi Arabia: a cross-sectional study. Z Gesundh wiss. 2018;26(6):607-12. https://doi.org/10.1007/s10389-018-0917-5

3. Li Q, Guan X, Wu P, Wang X, Zhou L, Tong Y, et al. Early transmission dynamics in Wuhan, China, of novel coronavirus-infected pneumonia. N Engl J Med. 2020 Mar;382(13):1199-207. https://doi.org/10.1056/NEJMoa2001316

4. World Health Organization - WHO. Novel coronavirus (COVID-19) situation. 2020. [cited 2020 March 13]. Available from: https://experience.arcgis.com/experience/685d0ace521648f8a5beeee 1b9125cd

5. Gamio L. The workers who face the greatest coronavirus risk. The New York Times. 2020 Mar 15 [cited 2020 Mar 15]. Available from: https://www.nytimes.com/interactive/2020/03/15/business/economy/coronavirus-worker-risk.html?action=click\&module=Top + Stories\& pgtype $=$ Homepage

6. Ali S, Zeb U, Muhammad A. Transmission routes and infection control of novel coronavirus-2019 in dental clinics: a review. J Islamabad Med Dental Coll. 2020;9(1):65-72. https://doi.org/10.35787/jimdc.v9i1.517

7. Meng L, Hua F, Bian Z. Coronavirus disease 2019 (COVID-19): emerging and future challenges for dental and oral medicine. J Dent Res. 2020 May;99(5):481-7. https://doi.org/10.1177/0022034520914246

8. Group of Interventional Respiratory Medicine, Chinese Thoracic Society. [Expert consensus for bronchoscopy during the epidemic of 2019 Novel Coronavirus infection (Trial version)]. Zhonghua Jie He He Hu Xi Za Zhi. 2020 Feb;43(0):E006. Chinese. https://doi.org/10.3760/cma.j.issn.1001-0939.2020.0006

9. Peng X, Xu X, Li Y, Cheng L, Zhou X, Ren B. Transmission routes of 2019-nCoV and controls in dental practice. Int J Oral Sci. 2020 Mar;12(1):9. https://doi.org/10.1038/s41368-020-0075-9

10. Scottish Dental Clinical Effectiveness Programme. Management of acute dental problems during COVID-10 pandemic. 2020 Mar 30 [cited 2020 Apr 12]. Available from: http://www.sdcep.org.uk/published-guidance/acute-dental-problems-covid-19/

11. American Dental Association. What constitutes a dental emergency? 2020 Mar 31 [cited 2020 Apr 13]. Available from: https://success.ada.org/ /media/CPS/Files/Open\%20Files/ADA_COVID19_Dental_Emergency_DDS.pdf

12. Turkish Dental Association. Dişhekimliğinde Acil Uygulamalar T.C. Sağlık Bakanlığı Sağlık Kurumlarına Yönelik Alınacak Uygulamaların Belirlenmesi. 2020 Mar 23 [cited 2020 Apr 23]. http://www.tdb.org.tr/icerik_goster.php?ld=3427

13. Spagnuolo G, De Vito D, Rengo S, Tatullo M. COVID-19 outbreak: an overview on dentistry. Int J Environ Res Public Health. 2020 Mar;17(6):2094. https://doi.org/10.3390/ijerph17062094

14. Capan BS, Akyuz S, Bahcecik N, Yarat A, Girgin F. Factors influencing career choices of dental students in a state university in Turkey. Clin Exp Health Sci. 2018;8(4):228-36.

15. Khader Y, Al Nsour M, Al-Batayneh OB, Saadeh R, Bashier H, Alfaqih M, et al. Dentists' awareness, perception, and attitude regarding COVID 19 and infection control: cross sectional study among Jordanian dentists. JMIR Public Health Surveill. 2020 Apr;6(2):e18798. https://doi.org/10.2196/18798

16. Bhagavathula AS, Aldhaleei WA, Rahmani J, Mahabadi MA, Bandari DK. Novel coronavirus (COVID-19) knowledge and perceptions: a survey of healthcare workers. MedRxiv. 2020. Preprint. https://doi.org/10.1101/2020.03.09.20033381

17. Kamate SK, Sharma S, Thakar S, Srivastava D, Sengupta K, Hadi AJ, et al. Assessing knowledge, attitudes and practices of dental practitioners regarding the COVID-19 pandemic: a multinational study. Dent Med Probl. 2020 Jan-Mar;57(1):11-7. https://doi.org/10.17219/dmp/119743

18. Manocha A, Tak L. A study to assess the level of awareness among dental health professionals (DHPs) concerning current pandemic of Covid-19 in Jaipur City. IJIRMPS. 2020;8(3):18-21.

19. Sabino-Silva R, Jardim AC, Siqueira WL. Coronavirus COVID-19 impacts to dentistry and potential salivary diagnosis. Clin Oral Investig. 2020 Apr;24(4):1619-21. https://doi.org/10.1007/s00784-020-03248-x

20. Singh Gambhir R, Singh Dhaliwal J, Aggarwal A, Anand S, Anand V, Kaur Bhangu A. Covid-19: a survey on knowledge, awareness and hygiene practices among dental health professionals in an Indian scenario. Rocz Panstw Zakl Hig. 2020;71(2):223-9.

21. Ahmed MA, Jouhar R, Ahmed N, Adnan S, Aftab M, Zafar MS, et al. Fear and practice modifications among dentists to combat novel coronavirus disease (COVID-19) outbreak. Int J Environ Res Public Health. 2020 Apr;17(8):2821. https://doi.org/10.3390/ijerph17082821

22. Kinariwala N, Samaranayake L, Perera I, Patel Z. Knowledge, awareness and perceptions of coronavirus disease 2019 (COVID-19) in a cohort of Indian dental professionals: a questionnaire-based study. Preprints. 2020;2020050442. https://doi.org/10.20944/preprints202005.0442.v1 
Assessment of dentists' awareness and knowledge levels on the Novel Coronavirus (COVID-19)

23. [cited 2020 Apr 23]. Available from: https://covid19bilgi.saglik.gov.tr/tr/alinan-karalar.html

24. Ather A, Patel B, Ruparel NB, Diogenes A, Hargreaves KM. Hargreaves. KM. Coronavirus disease 19 (COVID 19): implications for clinical dental care. J Endod. 2020 May;46(5):584-95. https://doi.org/10.1016/i.joen.2020.03.008

25. Corstiens PL, Abrams WR, Malamud D. Saliva and viral infections. Periodontol 2000. 2016 Feb;70(1):93-110. https://doi.org/10.1111/prd.12112

26. Coulthard P. Dentistry and coronavirus (COVID-19) - moral decision-making. Br Dent J. 2020 Apr;228(7):503-5. https://doi.org/10.1038/s41415-020-1482-1

27. Health and Safety Executive. Evaluating the protection afforded by surgical masks against influenza bioaerosols: gross protection of surgical masks compared to filtering facepiece respirators. Buxton; 2008 [cited 2020 Apr 23]. Available from: https://www.hse.gov.uk/research/rrpdf/rr619.pdf

28. Eggers M, Koburger-Janssen T, Eickmann M, Zorn J. In vitro bactericidal and virucidal efficacy of povidone-iodine gargle/mouthwash against respiratory and oral tract pathogens. Infect Dis Ther. 2018 Jun;7(2):249-59. https://doi.org/10.1007/s40121-018-0200-7

29. Kariwa H, Fujii N, Takashima I. Inactivation of SARS coronavirus by means of povidone-iodine, physical conditions, and chemical reagents. Jpn J Vet Res. 2004 Nov;52(3):105-12. https://doi.org/10.1159/000089211

30. Wang D, Hu B, Hu C, Zhu F, Liu X, Zhang J, et al. Clinical characteristics of 138 hospitalized patients with 2019 novel coronavirus-infected pneumonia in Wuhan, China. JAMA. 2020 Feb;323(11):1061-9. https://doi.org/10.1001/jama.2020.1585

31. Day M. Covid-19: ibuprofen should not be used for managing symptoms, say doctors and scientists. BMJ. 2020 Mar;368:m1086. https://doi.org/10.1136/bmi.m1086

32. Quadri FA, Jafer MA, Alqahtani AS, Mutahar SAB, Odabi NI, Daghriri AA, et al. Novel corona virus disease (COVID-19) awareness among the dental interns, dental auxiliaries and dental specialists in Saudi Arabia: a nationwide study. J Infect Public Health. 2020 June;13(6):856-64. https://doi.org/10.1016/i.jiph.2020.05.010 